\title{
Importance of information media on home science research
}

\author{
GITASREE GOSWAMI
}

Received: 17.06.2017; Revised: 21.10.2017; Accepted: 05.11.2017

Author for correspondence

\section{GITASREE GOSWAMI}

College of Home Science, Assam

Agricultural University, JORHAT

(ASSAM) INDIA

Email : goswamigitasree@gmail.

com
ABSTRACT : The present research entitled "importance of information media on Home Science research" was undertaken with the objectives to collect relevant material and develop an information media to assess its effectiveness. As an information media, a documentary was prepared by researcher and was evaluated by villagers, students and staffs. This study was carried out in Allahabad district of Uttar Pradesh. The script of a documentary was written in Hindi language so that villagers could be benefited and according to the story board clippings were shoot. Voiceover was done in studio after the shooting process and Cyber Link Power Director software was used during the editing process of documentary. The study was conducted during the year 2016 in Allahabad district of Uttar Pradesh. A close ended evaluation schedule was prepared to evaluate the documentary. Sixty respondents were selected purposively for the evaluation of the documentary. Data was analyzed by using suitable statistical tools like frequency, percentage and one way ANOVA. One way ANOVA was used to find out the effectiveness of the documentary. Ninety per-cents of staffs and students were aware about the parameters of the documentary and less by the villagers $(70 \%)$. From the tabulated value (3.162), overall results for six parameters were found. The first parameter, title of the documentary found significant result with calculated value 10.92. Likewise for duration and digital effect parameters, results were found non-significant with calculated values 0.64 and 1.19 , respectively, which were lower than tabulated value off (3.162). For parameters quality of voice and quality of picture, results were found significant with calculated values 6.45 and 14.35 , respectively. The last parameter was subject matter, in which result was found significant with calculated value 3.88 .

KEY WORDS: Documentary, Evaluation, Information media, Mass media

- HOW TO CITE THIS PAPER : Goswami, Gitasree (2017). Importance of information media on home science research. Asian J. Home Sci., 12 (2) : 531-534, DOI: 10.15740/HAS/AJHS/12.2/531-534. 